ARTICLE

DOI: $10.1057 /$ s41599-018-0122-8

\title{
Invertebrate disgust reduction in and out of school and its effects on state intrinsic motivation
}

\author{
Peter Wüst-Ackermann ${ }^{1}$, Christian Vollmer ${ }^{2}$, Heike Itzek-Greulich ${ }^{3}$ \& Christoph Randler ${ }^{4}$
}

\begin{abstract}
Invertebrates are used in environmental, biology, and science education. However, they can elicit disgust, which can be detrimental for motivational and learning outcomes. In addition, practical work including hands-on interaction with living invertebrates could be a viable way to reduce invertebrate disgust and strengthen state intrinsic motivation. Moreover, Big-Five personality may explain the students' reaction to the exposure with live invertebrates. Therefore, the present study tested the effects of an intervention with living invertebrates on disgust and state intrinsic motivation in a sample of 1861 students (age 10-12 years). Moreover, we tested whether an in-school or an out-of-school intervention was more successful in reducing disgust as compared to the control group. While disgust was measured at pre- and post-test, trait motivation was measured at pre-test and state intrinsic motivation was measured at post-test. Results show that while both treatment conditions reduced disgust more than the control condition, the out-of-school condition had a more pronounced disgust reduction than the school condition. Disgust was negatively related to state intrinsic motivation, but state intrinsic motivation was equally high in both treatment conditions (school and university). Extraversion was negatively and neuroticism was positively related to disgust. Big-Five personality was generally associated with state intrinsic motivation. In conclusion, invertebrate disgust can be successfully reduced by an intervention with live invertebrates. The workstation-based intervention with live invertebrates is useful in different settings, both in and out of school and effective with invertebrate species, especially with snails and mealworms, because children's disgust for these species was significantly reduced and lower disgust was related to higher state intrinsic motivation.
\end{abstract}

\footnotetext{
${ }^{1}$ University of Education Heidelberg, Department of Biology, Im Neuenheimer Feld 561, 69120 Heidelberg, Germany. ${ }^{2}$ Independent Researcher, Schiffsgasse 4, 69117 Heidelberg, Germany. ${ }^{3}$ Independent Researcher, 69242 Mühlhausen, Germany. ${ }^{4}$ Department of Biology, Eberhard Karls University Tübingen, Auf der Morgenstelle 24, 72076 Tübingen, Germany. Correspondence and requests for materials should be addressed to

C.R. (email: christoph.randler@uni-tuebingen.de)
} 


\section{Introduction}

isgust is a negative emotion that is triggered by zoonotic poison/pathogen-protection mechanisms as a reaction against potential contagion and is expressed by aversive or avoidance reactions (Curtis et al., 2004; Kasperbauer, 2015). Disgust makes humans sensitive to potential contaminants and thus generates numerous false-positive responses (Kasperbauer, 2015). This can be explained by the smoke detector model: It is better to react towards a potential threat as a false-positive response (this means, a person avoids an animal although is not harmful) because the costs in evolutionary terms are low. Responding to an invertebrate with disgust although it is not harmful has only low evolutionary costs. However, if the smoke detector's response is too insensitive, smoke will not be detected although it occurred (Nesse, 2005). In this example, a person would not respond to a disgusting animal although it is harmful. The evolutionary costs can be high (injury, even death). Although animals in general may transmit zoonotic diseases, human aversive responses to animals are tied to certain species: while, in general, larger animals may elicit fear, invertebrates are among the species that elicit considerable disgust (e.g., millipede and edible snail (Breuer et al., 2015)) and fear (slug, leech, cockroach and spider (Ware et al., 1994)).

Invertebrate disgust reduction in the classroom. Why should students be exposed to disgusting animals at school to induce a disgust reduction? The main argument comes from environmental education, where the acceptance of feared and less liked species has an influence on their conservation. Because most people like the charismatic megafauna, it is important to also draw attention towards disliked animals to improve environmental concern and to understand their role in nature (Ballouard et al., 2015; Bixler and Floyd, 1999).

While the introduction of living animals to the classroom may have several benefits like an increase in student motivation, living animals also elicit fear and disgust (Randler et al., 2013). In biology lessons, students are exposed to different (living) animals, and students may perceive some as more and some as less disgusting. Living invertebrates are among the animals rated as most disgusting (snail, earthworm, woodlouse (Randler et al., 2013)). Students need guidance in coping with the presence of disgust-eliciting living invertebrates that may lead to a disgust reduction.

Reduction of disgust is regarded as beneficial for student motivation (Randler et al., 2013). Negative emotions, such as anxiety and disgust, are related to lower achievement (Randler et al., 2005) and less willingness to protect disgusting species (Prokop and Fančovičová, 2013), while positive emotions, like interest and well-being are positively related to learning achievement and motivation (Randler et al., 2012b). Disgust reactions are usually hard to unlearn (Kasperbauer, 2015), but studies in clinical settings on phobia (e.g., spider or snake phobia) showed that an intervention with living animals can reduce this phobia, lending support for these types of intervention (Ballouard et al., 2012).

Hands-on activities with living invertebrates in the classroom may be effective in reducing students' disgust for certain species. For example, Hummel et al. (2012) showed that disgust reduction is possible with living animals in the classroom, and, similarly, Randler et al. (2012b) showed that dissecting a fish reduces the specific situational disgust towards this task. On the other hand, there are many "false positives" (Klieger and Siejak, 1997) where students report disgust but may not act disgusted when confronted with those species-if this is the case, disgust reduction by a school intervention with living invertebrates would be easier to accomplish. For example, a lesson with living snails successfully reduced snail disgust in fifth-graders (Prokop and Fančovičová, 2016).

Out-of-school learning. Over the last three decades, out-ofschool learning has been one of the substantial topics (Rennie, 2014) in the fields of formal and informal learning (Salmi, 2012). It offers learning arrangements in accordance with the school schedule and the curriculum, but in extracurricular settings, facilities, and institutes outside the school building (Rennie, 2014). Out-of-school learning (including interactive science centers, museums, aquaria, and zoos (Rennie and McClafferty, 1995)) can foster research interests and may stimulate selfdirected learning (Wilde and Urhahne, 2008). Braund and Reiss (2006) describe five targets for out-of-school science learning, which should ideally be implemented and fulfilled in practice: (a) improved development and integration of professional concepts, (b) advanced and authentic practical work, (c) access to rare material (in our study: invertebrates) and real research, (d) attitude towards natural sciences in school: encouraging further learning, and (e) cooperation and responsibility for learning (social learning). Another aspect of out-of-school learning is involvement in authentic practical field work (Winterbottom, 2017). Glowinski and Bayrhuber (2011) reported a significant correlation between the involvement of students in the classroom and the interest in experiments, context, and authenticity.

State intrinsic motivation. Motivation is a positive predictor of achievement in science (Areepattamannil et al., 2011). The theoretical background of intrinsic motivation is based on the selfdetermination theory (SDT) of Deci and Ryan (Deci and Ryan, 1991). In particular, a perceived high level of competence and autonomy leads to an intrinsically motivated behavior (Ryan and Deci, 2000). Some studies showed that a higher level of selfdetermination positively influences the learning process (Grolnick and Ryan, 1987). Therefore, we chose intrinsic motivation as an important variable to assess whether disgust is negatively related to intrinsic motivation.

Personality. We here used personality as an important, noncognitive variable related to the learning process. Previous work showed that personality is in general related to achievement (for example, when related to general school achievement (Arbabi et al., 2015)). This study, as most others, is based on the Big-Five personality domains, the most widely used conceptualization of personality. This includes the domains openness (being interested in new topics), conscientiousness (being a conscientious and exactly working person), extraversion (open to other people, talkative), agreeableness (being kind and agreeable), and neuroticism (which is a kind of emotional instability). Studies report usually a positive influence of the personality trait of conscientiousness on achievement (Vedel, 2014). However, specific settings in teaching and learning have rarely been investigated in respect to personality. Usually, general learning outcomes have been assessed, rather than how personality is related to outcomes in short-term teaching and learning sequences. Moreover, the relationship between personality and disgust during such a learning sequence has not been studied, but we expect correlations with disgust, because both constructs are related with learning achievement.

Present study. Building on previous small scale studies (Randler et al., 2012a), in this present study, a large controlled field trial in many different settings with questionnaires was carried out. First, 
we investigated the effectiveness of living animals for increasing interest, motivation, and achievement comparing an in school or an out-of-school intervention with living invertebrates. We found that the out-of-school intervention is more effective than an equivalent lesson at school where girls showed higher achievement after treatment than boys (Wüst-Ackermann et al., 2018). Conscientiousness was a predictor of invertebrate-inspired achievement. The correlations with achievement were stronger for state motivation than for trait motivation (Randler et al., 2012b).

This paper now wants to address the major question: Will disgust decrease and can a decrease in disgust be attributed to both treatments (school/university) as compared to the control group? Our secondary hypothesis was whether, after a successful disgust reduction by treatment, the lower disgust was related to higher state intrinsic motivation. Third, we were curious to see whether Big-Five personality was associated with disgust and state intrinsic motivation during practical work with living invertebrates in the young age of 10-12 year olds. In comparison to previous work, we addressed these questions by a large sample size (1861 students) from many different schools and we further checked if the environment (classroom teaching vs. a field trip to the university) is more effective in potentially reducing disgust. Additionally, we employed a control group in this controlled field trial. Additionally, to reflect the German school system and to enhance generalizability, we did the study in different stratifications (upper track, Gymnasium; intermediate track, "Realschule").

\section{Methods}

Participants. The sample size was $N=1861$ students $(51.0 \%$ girls) of grade $5(n=784)$ and $6(n=1077)$ from the intermediate track (Realschule, $n=1048$ ) and upper track (Gymnasium, $n=$ 813) of secondary education. The age range was 10-12 years. Participating schools and classrooms were contacted by convenience sampling in Germany. That is, the established contacts from the collaboration of university and schools (school practice semester and university students' contacts) were used to attract classrooms for the present study. Moreover, there was a note on the website and classes were invited to apply for participation in the intervention. Thus, it was possible for all teachers to participate. The study was carried out between April 2014 and December 2016. The students were informed that the participation was voluntary and that the questionnaires were only used for anonymous scientific evaluation at the university and, therefore, unrelated to their grades.

Study design. The students observed and interacted with living invertebrates at six workstations. The treatment was about $3 \mathrm{~h}$ with a 20 min break after the first three workstations. The living invertebrates used were the giant African land snail (Lissachatina fulica), millipedes (Spirostreptidae sp. 6 and Archispirostreptus gigas), phasmids (Eurycantha calcarata, Extatosoma tiaratum, Heteropteryx dilatata, and Phyllium giganteum), the Madagascar hissing cockroach (Gromphadorhina portentosa), and the mealworm beetle (Tenebrio molitor) (Wüst-Ackermann et al., 2018).

The study included a pre-test immediately before the intervention and a post-test immediately after the intervention in the classroom. There were three conditions with different treatments: the control condition, the school condition, and the university condition (Fig. 1). The study had high ecological validity because the teachers were given the choice of whether they wanted to employ the school condition with the experts visiting their school or the university condition. The treatment is unique in the way that exact the same lesson with the same material and methods can be taught at the regular school or at university. The students filled out the questionnaires on pre-test prior to the intervention and post-test immediately after the intervention, but the control condition did not receive any treatment other than photographs of the invertebrates shown prior to the pre-test and post-test. In addition to this, the school group received the intervention (lesson on living invertebrates) at school, while the university group received the same intervention at the university. The treatment was implemented by two university students ("experts") experienced in the handling of the invertebrates. These experts underwent a standardized training by a biology scientist and the animal keeper before the intervention started. They participated in a seminar at the University of Education in Heidelberg where the treatment was practiced together with other university students and one of the biology scientists.

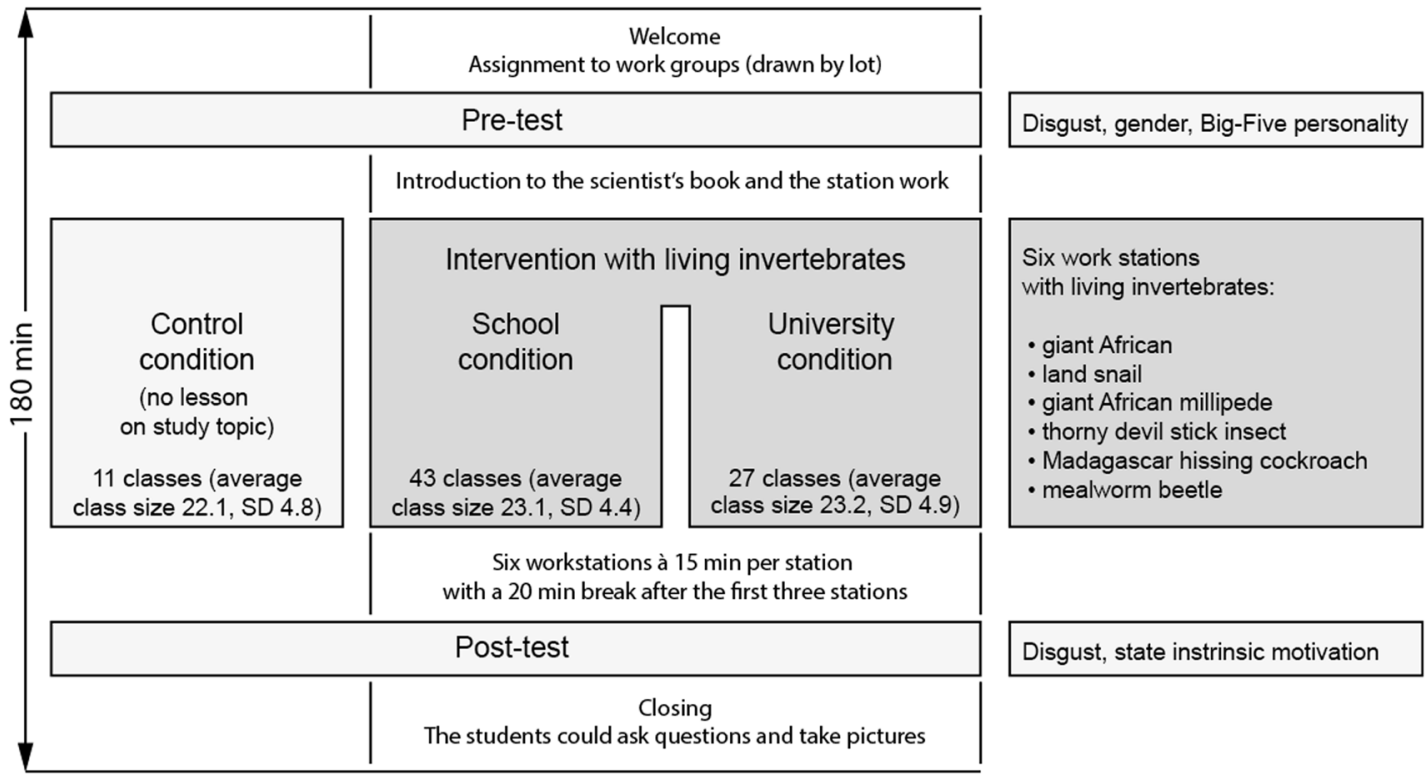

Fig. 1 Overview over the study design. Both interventions received the same teaching but differed in the setting (university-based vs. school-based) 
Measures. The questionnaire included an invertebrate disgust scale (pre-test and post-test; see Fig. 1) which explores negative attitudes towards the invertebrates, Big-Five personality (pretest), and state intrinsic motivation (implemented in the posttest). The students' gender was recorded as part of the personal code, which was used to link the pre- and post-test questionnaires.

Invertebrate disgust. An invertebrate disgust scale was created. The scale (15 items, see Appendix A; implemented in the pre-test and post-test) focusses on the topic of the intervention. Confirmatory factor analysis in Mplus 7 (Muthén and Muthén, 1998-2012) using the WLSMV estimator showed that pre-test and post-test scores fitted well to a five-factorial second-order model where each invertebrate was assigned its own latent factor and a higher order level for general invertebrate disgust. Factor loadings (standardized regression coefficients with standard errors), residual variances of the subscales and model fit information are shown in Appendix B. Pre-test and post-test scores were highly correlated $(r=0.78)$, which indicates temporal consistency between pre- and post-test. Cronbach's $\alpha$, calculated with SPSS 24 (IBM Corp, 2015), was 0.93 for the pre-test and 0.93 for the post-test.

Personality measure. The short 10-item inventory for Big-Five personality (2003) was applied, covering the dimensions extraversion, conscientiousness, emotional stability (neuroticism), agreeableness, and openness. The inventory contains 10 questions, with 2 items per dimension. Personality was included since non-cognitive factors may also substantially contribute to learning and instruction (Vedel, 2014) and the Big-Five personality measure is one of the most widely used conceptualizations of personality.

State intrinsic motivation. State intrinsic motivation is related to learning because high scores on intrinsic motivation are related to higher scores in learning (Seybold et al., 2014). State intrinsic motivation was measured with the short scale of intrinsic motivation (KIM) (Wilde et al., 2009); 5-point Likert-scale: 5 (totally agree) to 1 (totally disagree). This scale has 12 items and 4 subscales with 3 items each (interest, competence, choice, and tension Wilde et al., 2012). In this study, we reinvestigated the factorial model, because the sample size of the present study was ten times larger than the original sample size (Wilde et al., 2009). Building up on Wilde et al., (2009), a 4-factorial confirmatory factor analysis for categorical items with WLSMV estimator (Mplus 7) showed acceptable model fit (Appendix C) and confirmed the model of the original publication. Cronbach's $\alpha$, calculated with SPSS 24, was 0.86 for interest, 0.88 for competence, 0.74 for choice, and 0.72 for tension.

Statistical analyses. Two-level regression analyses were conducted in Mplus 7 to account for the clustering of the data. The students were nested in classrooms and this lack of statistical independence is indicated by the intraclass correlation coefficient with higher values indicating higher dependency (Table 1). The disgust, state intrinsic motivation and Big-Five personality variables were measured on the student level while the treatment condition was a class-level variable, because whole classes were assigned to one of the treatments (school/university condition) or to the control condition. The effect sizes are given as $R^{2}$ on the student level, as $R^{2}$ on the class level, and as a composite/overall effect size (Snijders and Bosker's $R^{2}$ ) referring to the calculation method of Snijders and Bosker (Snijders and Bosker, 1994). Continuous variables were $\mathrm{z}$-standardized for the MLA regression analyses and dummy variables were used for the numerical and categorical variables sex, school type, and the treatment conditions. There was attrition on the class level; two classes from the control condition did not fill out the post-test (see Table 1) because the teacher did not administer the questionnaire at the post-test.

Ethical considerations. The study does not include any experiments with humans. The study was carried out during regular school teaching and followed the guidelines of the Forschungskommission of the University of Education Heidelberg. The methods were carried out in accordance with the relevant guidelines and regulations. Informed consent was obtained from all participants, teachers, and principals.

\section{Results}

Preliminary analyses. At the pre-test and the post-test, disgust was highest for the thorny devil stick insect and for the

Table 1 Disgust, scale descriptives by wave and treatment

\begin{tabular}{|c|c|c|c|c|c|c|c|c|c|c|c|c|c|c|c|c|c|c|}
\hline & & \multirow[b]{2}{*}{$\mathbf{M}$} & \multirow[b]{2}{*}{ (SD) } & \multirow[b]{2}{*}{$n$} & \multirow[b]{2}{*}{$\boldsymbol{M}$} & \multirow[b]{2}{*}{ (SD) } & \multirow[b]{2}{*}{$n$} & \multirow[b]{2}{*}{$\boldsymbol{M}$} & \multirow[b]{2}{*}{ (SD) } & \multirow[b]{2}{*}{$n$} & \multirow[b]{2}{*}{$\boldsymbol{M}$} & \multirow[b]{2}{*}{ (SD) } & \multirow[b]{2}{*}{$\boldsymbol{N}$} & \multirow[b]{2}{*}{ ICC } & \multirow[t]{2}{*}{$\begin{array}{l}\text { On } \\
\text { student } \\
\text { level }\end{array}$} & \multirow[t]{2}{*}{$\begin{array}{l}\text { On } \\
\text { class } \\
\text { level }\end{array}$} & \multicolumn{2}{|c|}{$\begin{array}{l}\text { Total } \\
\text { missing }\end{array}$} \\
\hline & & & & & & & & & & & & & & & & & $n$ & $\%$ \\
\hline Total disgust & Pre & 2.74 & $(0.95)$ & 243 & 2.67 & $(1.04)$ & 982 & 2.82 & $(1.01)$ & 626 & 2.73 & $(1.02)$ & 1851 & 0.11 & 10 & $0(0)^{a}$ & 10 & 0.5 \\
\hline Snail & Post & 2.44 & $(1.21)$ & 197 & 1.93 & $(1.15)$ & 974 & 2.03 & $(1.13)$ & 626 & 2.02 & $(1.16)$ & 1797 & 0.10 & 21 & $2(43)$ & 64 & 3.4 \\
\hline \multirow[t]{2}{*}{ Millipede } & Pre & 2.66 & $(1.23)$ & 243 & 2.60 & $(1.25)$ & 983 & 2.77 & $(1.20)$ & 626 & 2.66 & $(1.23)$ & 1852 & 0.10 & 9 & $0(0)$ & 9 & 0.5 \\
\hline & Post & 2.33 & $(1.33)$ & 197 & 2.12 & $(1.29)$ & 974 & 2.14 & $(1.31)$ & 626 & 2.15 & $(1.31)$ & 1797 & 0.12 & 21 & $2(43)$ & 64 & 3.4 \\
\hline \multirow[t]{2}{*}{ Thorny devil } & Pre & 3.06 & $(1.10)$ & 238 & 2.90 & $(1.22)$ & 963 & 3.06 & $(1.21)$ & 626 & 2.97 & $(1.21)$ & 1827 & 0.10 & 34 & $0(0)$ & 34 & 1.8 \\
\hline & Post & 2.51 & $(1.33)$ & 193 & 2.40 & $(1.34)$ & 971 & 2.38 & $(1.35)$ & 626 & 2.40 & $(1.34)$ & 1790 & 0.08 & 28 & $2(43)$ & 71 & 3.8 \\
\hline Cockroach & Pre & 2.93 & $(1.16)$ & 240 & 2.92 & $(1.27)$ & 965 & 3.05 & $(1.26)$ & 623 & 2.96 & $(1.25)$ & 1828 & 0.08 & 33 & $0(0)$ & 33 & 1.8 \\
\hline
\end{tabular}




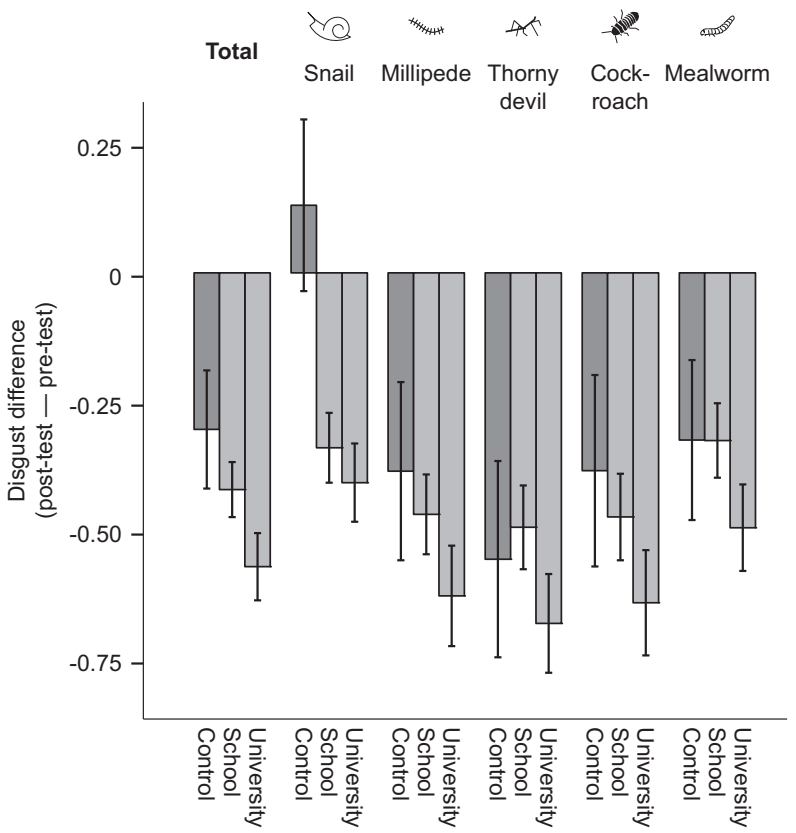

Fig. 2 The difference in perceived disgust from pre-test to post-test by treatment. Disgust differs between the pre-test and post-test in the three conditions (control condition, university-based, and school-based treatments). Error bars are $95 \% \mathrm{Cl}$

Madagascar hissing cockroach, and lowest for the giant African land snail (Table 1). In all conditions (control, school, and university), disgust was generally significantly lower at the post-test than at the pre-test ( $p<0.001$; paired samples $t$-tests), but not for snail disgust in the control condition ( $p=0.144$; Fig. 2$)$. The reduction in disgust was strongest for the thorny devil stick insect, the Madagascar hissing cockroach, and the giant African millipede (Fig. 2). The intraclass correlation (ICC) was 0.11 for total disgust (pre-test) and 0.10 for total disgust (post-test), see Table 1. Pre-intervention differences in the outcome variables across the three groups (the two treatment groups and the control group) were investigated with ANOVA (Bonferroni-corrected post-hoc tests) and pre-test disgust was higher in the university condition than in the school condition (total disgust as well as the snail, millipede, and thorny devil subscale). The control condition did not significantly differ in pre-test disgust from the two treatment conditions. Concerning the attrition on the class level at the post-test, the two classes that did not fill out the post-test did not significantly differ in their pre-test disgust (total disgust and all subscales) when compared to the other classes of the control condition. The correlation of the total disgust raw scores pre-test/post-test was $r=0.68$ (Table 2). The correlation of the latent factors was higher, see Appendix B.

The Big-Five personality domains were significantly correlated with pre- and post-test disgust, except for agreeableness. The state intrinsic motivation variables were also significantly correlated with pre- and post-test disgust. Neuroticism and pressure/tension were positively correlated with disgust while the association was negative for the other personality and state intrinsic motivation variables (Table 2). Gender was unrelated to disgust.

Intervention effects on post-test disgust. The effects of pre-test disgust on post-test disgust were investigated via multilevel regression analyses while controlling for treatment on the class level. The school condition was used as reference group (Table 3). Post-test disgust was significantly related to pre-test disgust for the total disgust measure as well as for all disgust subscales. Total disgust was reduced by both treatment conditions as indicated by the significantly higher disgust for the control condition (Model 1, Table 3). Moreover, when controlling for the Big-Five variables, the university condition had significantly lower disgust than the school and control conditions (Model 2, Table 3). Also, there was a significant reduction of snail disgust for both treatment conditions and a significant reduction of mealworm disgust for the university condition.

Students with lower values in extraversion reported significantly higher post-test disgust for the total and all subscales. Higher neuroticism was related to higher post-test disgust (total, thorny devil, cockroach, and mealworm). Moreover, there was a significantly positive association between conscientiousness and higher disgust for the thorny devil. Model 1 (Table 3) explained $46 \%$ of variance in the dependent variable post-test disgust (total). Introducing the Big-Five as covariates added another 1\% of explained variance (Model 2, Table 3).

Intervention effects on state intrinsic motivation. The relationship of disgust (total disgust at pre- and post-test) with state intrinsic motivation was investigated via multilevel regression analyses while controlling for treatment on the class level. The school condition was again used as reference group (Table 4). Post-test disgust was significantly related to all four dimensions of state intrinsic motivation. While this relation was negative for interest, competence, and choice, the relation between disgust and tension was positive. The students of the university condition had significantly lower tension than the school and the control conditions, but the treatment was unrelated to the motivational variables interest, competence, and choice.

The Big-Five personality had several effects on the state intrinsic motivation. Agreeableness and conscientiousness were positively related to interest and competence. Neuroticism was negatively related to competence and choice, but positively related to tension. Openness was positively related to interest, competence, and choice.

The explained variance ranged between $9 \%$ for choice and $18 \%$ for interest (Table 4). When comparing the results from Tables 3 and 4, the Big-Five variables had more impact on the state intrinsic motivation (interest and competence) than on the posttest disgust.

\section{Discussion}

Disgust reduction. The study showed that a reduction in disgust due to an educational intervention is possible and effective. In line with previous work, we here showed that disgust is lower after an intervention with living invertebrates. This is comparable with a study about snakes (Ballouard et al., 2012) and spiders, where Wagler and Wagler (2017) reported that a treatment group with exposure to living spiders exhibited a steady and maintained decrease in the levels of fear, perceived danger and disgust across the time. Concerning snails, snail disgust was significantly reduced by the treatment and this is comparable to another study where a lesson with living snails successfully reduced snail disgust in fifth-graders (Prokop and Fančovičová, 2016). Thus, exposure to animals of fearful or disgusting taxa might be a method to reduce these basic negative emotions which, in turn, may foster the attitude towards their function in ecosystems and conservation. The reduction of disgust is a worthwhile task because disgust negatively impacts on motivation and achievement (Randler et al., 2005; Randler et al., 2013) and the willingness to protect those (Prokop and Fančovičová, 2013). However, the study also showed that photographs reduced disgust. This is an interesting result and it clearly shows that all future studies should have a sufficient number of controls when claiming that disgust is 
Table 2 Correlations of the study variables

\begin{tabular}{|c|c|c|c|c|c|c|c|c|c|c|c|}
\hline & & 1 & 2 & 3 & 4 & 5 & 6 & 7 & 8 & 9 & 10 \\
\hline 1 & Disgust, total (pre-test) & & & & & & & & & & \\
\hline 2 & Disgust, total (post-test) & $\star \star \star 0.68$ & & & & & & & & & \\
\hline 3 & Extraversion & $\star \star \star-0.32$ & 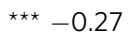 & & & & & & & & \\
\hline 5 & Conscientiousness & $\star-0.06$ & * -0.05 & $\star \star \star 0.09$ & $\star \star \star * 0.32$ & & & & & & \\
\hline 6 & Neuroticism & ${ }^{\star \star \star} 0.29$ & ${ }^{\star \star \star} 0.24$ & $\star \star \star *-0.26$ & -0.04 & $\star \star \star-0.08$ & & & & & \\
\hline 7 & Openness & $\star \star \star-0.09$ & ${ }^{\star *}-0.08$ & ${ }^{\star \star *} 0.13$ & ${ }^{\star \star \star} 0.24$ & ${ }^{\star \star \star} 0.21$ & -.03 & & & & \\
\hline 10 & Choice & $\star \star \star-0.19$ & $\star \star \star \star-0.24$ & ${ }^{\star \star \star} 0.13$ & ${ }^{\star \star \star} 0.09$ & ${ }^{\star \star \star} 0.08$ & $\star \star \star-0.13$ & ${ }^{\star \star \star} 0.12$ & $\star \star \star * 0.49$ & $\star \star \star \star 0.59$ & \\
\hline 11 & Pressure/tension & $\star \star \star 0.24$ & $\star \star \star 0.33$ & $\star \star \star-0.13$ & 0.01 & -0.01 & ${ }^{\star \star \star} 0.15$ & -0.03 & *-0.05 & -0.03 & 0.02 \\
\hline
\end{tabular}

lowered or reduced by a given intervention. This result may be also obtained because of pre-/post-test sensitization or desensitization.

Pre- and post-test disgust were significantly correlated, which was an expected result because disgust is mainly a trait variable that cannot be easily changed. However, as disgust also has a state component, fluctuations in disgust are also expected, which has been shown in this study where disgust was lowered by an intervention.

School vs. out-of-school practical work. The university group showed a stronger decline in disgust, which emphasizes the quality of the out-of-school setting. Given that all other experimental conditions were similar, we here show that the out-ofschool setting has a higher effect. An explanation could be that the authentic teaching of biological content in the out-of-school setting is more successful in generating interest in science, a positive attitude towards science and commitment to science activities (Woods-McConney et al., 2013). This also can be attributed, for example, to the novel environment (novel field trip phenomenon Falk et al., 1978). In general, both practical work conditions (in school and out-of-school) decreased the disgust significantly when compared to the control group This is in contrast to another study on disgust reduction through practical work with live woodlice which found no effect (Fančovičová and Prokop, 2017). Thus, we can conclude that the intervention based on workstations with live invertebrates is applicable both, in the school setting and out of school.

State intrinsic motivation. Post-test disgust was significantly related to all four dimensions of state intrinsic motivation. While this relation was negative for interest, competence, and choice, the relation between disgust and tension was positive. The students of the university condition had significantly lower tension than the school and the control conditions, but the treatment was unrelated to the motivational variables interest, competence, and choice. This shows that an educational intervention can also take place at school, because motivational variables did not significantly differ. However, the feeling of pressure/tension was lower at the university, which may show that students feel less under pressure when they study outside their school. This may be related to a higher well-being, a variable that could be measured in additional, future studies.

Personality. The Big-Five personality had several effects on the state intrinsic motivation. Agreeableness and conscientiousness were positively related to interest and competence. Neuroticism was negatively related to competence and choice, but positively related to tension. Openness was positively related to interest, competence, and choice. Personality has been recently identified as an important, non-cognitive predictor of learning outcomes (Furnham et al., 2009). In this study, we add to the well-known achievement aspects by showing a relationship between personality and motivation/disgust. We here used the Big-Five personality because it is among the most widely used personality assessments, but other, more biological oriented personality scales may be useful, such as the BIS/BAS (Carver and White, 1994). This will be addressed in a future study. As another small, but incremental aspect, we here replicated the factor structure of the KIM (Wilde et al., 2009). These authors suggest a four-factor scale with three items each and we here show using confirmatory factor analysis that this factor structure is valid across a very large sample size. This adds to the quality of this measurement.

Gender. Gender was unrelated to disgust that is contrary to the findings of Prokop und Jančovičová (Prokop and Jančovičová, 2013) or the review by Oaten et al. (Oaten et al., 2009), which report higher disgust sensitivity for females. However, in general, gender effects in attitude seem to be overestimated and Herzog, (2015) notes a considerable overlap between men and women, with much greater within-sex than between-sex variation.

As a limitation, the schools and classes were not randomly selected and not randomly attributed to the three conditions. A strength of the present study was the implementation as a multisite experiment. Disgust was reduced in both treatment conditions when compared to the control group, and this indicates that not only the treatment effects are substantial but also that these positive effects hold across different contexts and the treatment can be generalized and successfully transferred to other contexts (Pituch et al., 2005). Another benefit of this study is the choice of different taxa of invertebrates, thus, the results can also be generalized or compared across different invertebrate species.

Implications. This study has several implications for teaching invertebrate education related to disgust reduction. First, disgust could be reduced in both educational settings, thus, we suggest doing invertebrate education also in the classroom and we encourage teachers doing this. There are many practical suggestions and concepts for teaching common and easily accessible invertebrates in normal classrooms (Hummel and Randler, 2012). Second, we also found that in the control group were the photos were used for pre- and post-test, also a small reduction took place, supporting the idea to test this phenomenon in other settings and to prove its generalizability. Further, we consider this study useful as it is applicable to other parts of invertebrate 


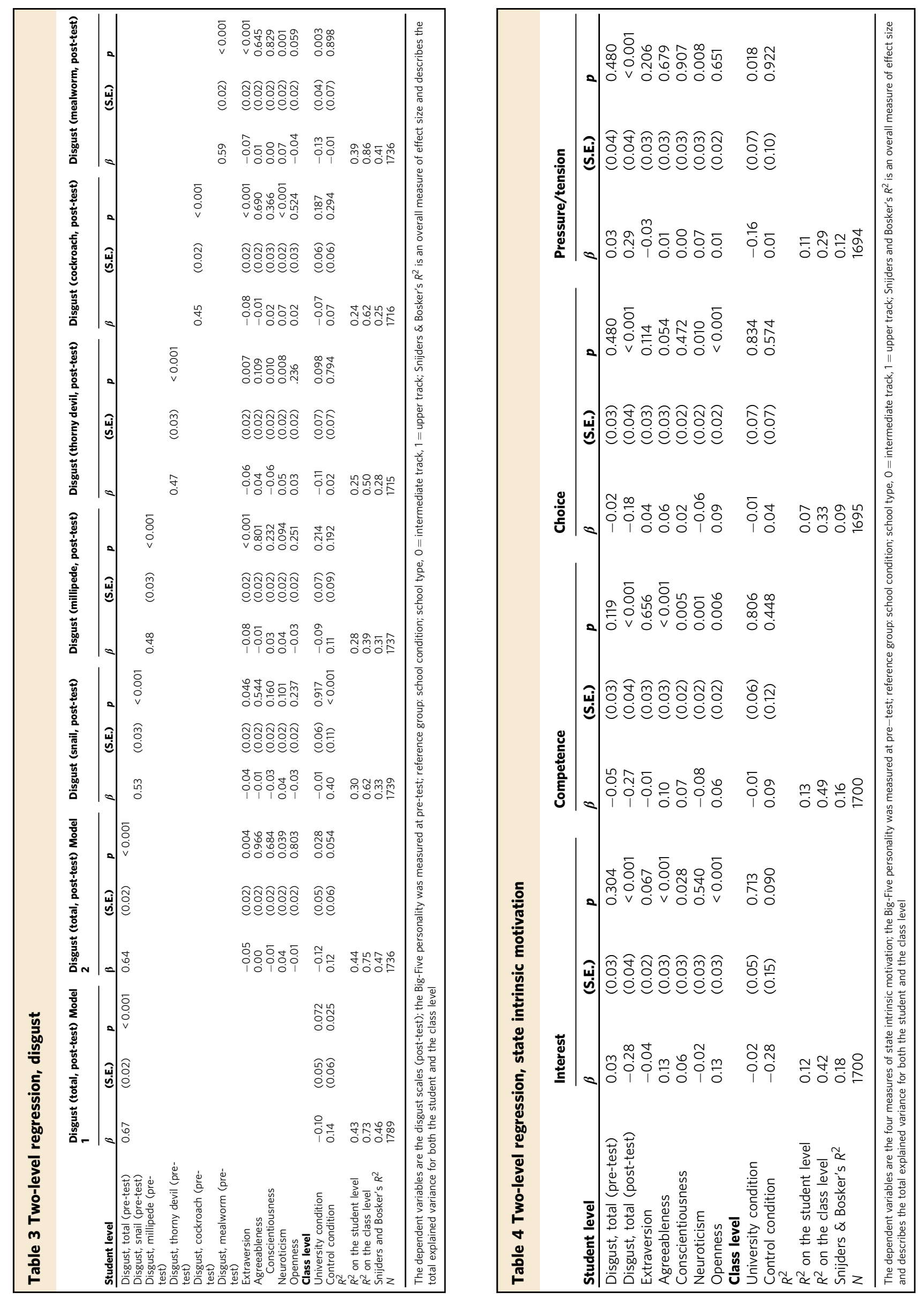


education, as we suppose that other disgusting vertebrates should also be taught in school lessons and this will also lead to a reduction disgust.

\section{Conclusions}

As a conclusion, we encourage teachers and people responsible for out-of-school settings not to avoid animals, especially invertebrates that are on a first sight disgusting, but rather incorporate these animals into teaching, irrespective whether these are inschool or out-of-school settings.

Received: 5 January 2018 Accepted: 15 May 2018

Published online: 03 July 2018

\section{References}

Arbabi T, Vollmer C, Dörfler T, Randler C (2015) The influence of chronotype and intelligence on academic achievement in primary school is mediated by conscientiousness, midpoint of sleep and motivation. Chronobiol Int 32 (3):349-357

Areepattamannil S, Freeman JG, Klinger DA (2011) Influence of motivation, selfbeliefs, and instructional practices on science achievement of adolescents in Canada. Social Psychol Educ 14(2):233-259

Ballouard J-M, Ajtic R, Balint H, Brito JC, Crnobrnja-Isailovic J, Desmonts D et al. (2015) Schoolchildren and one of the most unpopular animals: Are they ready to protect snakes? Anthrozoös 26(1):93-109

Ballouard J-M, Provost G, Barré D, Bonnet X (2012) Influence of a field trip on the attitude of schoolchildren toward unpopular organisms: An experience with snakes. J Herpetol 46(3):423-428

Bixler RD, Floyd MF (1999) Hands on or hands off?: Disgust sensitivity and preference for environmental education activities. J Environ Educ 30(3):4-11

Braund M, Reiss M (2006) Towards a more authentic science curriculum: The contribution of out-of-school learning. Int J Sci Educ 28(12):1373-1388

Breuer GB, Schlegel J, Kauf P, Rupf R (2015) The importance of being colorful and able to fly: Interpretation and implications of children's statements on selected insects and other invertebrates. Int J Sci Educ 37(16):2664-2687

Carver CS, White TL (1994) Behavioral inhibition, behavioral activation, and affective responses to impending reward and punishment: The BIS/BAS Scales. J Pers Soc Psychol 67(2):319-333

Curtis V, Aunger R, Rabie T (2004) Evidence that disgust evolved to protect from risk of disease. Biol Sci 271:S131-S133. Suppl 4

Deci EL, Ryan RM (1991) A motivational approach to self: Integration in personality. In: Dienstbier R (ed.) Nebraska symposium on motivation: vol. 38: Perspectives on motivation. University of Nebraska Press, Lincoln, pp. $237-288$

Falk JH, Martin WW, Balling JD (1978) The novel field-trip phenomenon: Adjustment to novel settings interferes with task learning. J Res Sci Teach 15 (2):127-134

Fančovičová J.,Prokop P,(2017) Effects of hands-on activities on conservation, disgust and knowledge of woodlice Eurasia J Math Sci Technol Educ 14 (3):721-729

Furnham A, Monsen J, Ahmetoglu G (2009) Typical intellectual engagement, Big Five personality traits, approaches to learning and cognitive ability predictors of academic performance. Br J Educ Psychol 79(Pt 4):769-782

Glowinski I, Bayrhuber H, (2011) Student labs on a university campus as a type of out-of-school learning environment: Assessing the potential to promote studends' interest in science Int J Environ Sci Educ 6(4):371-392

Gosling SD, Rentfrow PJ, Swann WB (2003) A very brief measure of the Big-Five personality domains. J Res Pers 37(6):504-528

Grolnick WS, Ryan RM (1987) Autonomy in children's learning: An experimental and individual difference investigation. J Pers Soc Psychol 52(5):890-898

Herzog HA (2015) Gender differences in human-animal interactions: A review. Anthrozoös 20(1):7-21

Hummel E, Randler C (2012) Living animals in the classroom: A meta-analysis on learning outcome and a treatment-control study focusing on knowledge and motivation. J Sci Educ Technol 21(1):95-105

Hummel E, Randler C, Prokop P (2012) Practical work at school reduces disgust and fear of unpopular animals. Soc Anim 20(1):61-74

IBM Corp (2015) IBM SPSS Statistics for Windows. IBM Corp, Armonk, NY, Version 24.0

Kasperbauer TJ (2015) Animals as disgust elicitors. Biol Philos 30(2):167-185

Klieger DM, Siejak KK (1997) Disgust as the source of false positive effects in the measurement of ophidiophobia. J Psychol 131(4):371-382
Muthén LK and Muthén BO (1998-2012) Mplus user's guide. 7th edn. Muthén \& Muthén, Los Angeles, CA

Nesse RM (2005) Natural selection and the regulation of defenses. Evol Hum Behav 26(1):88-105

Oaten M, Stevenson RJ, Case TI (2009) Disgust as a disease-avoidance mechanism. Psychol Bull 135(2):303-321

Pituch KA, Whittaker TA, Stapleton LM (2005) A comparison of methods to test for mediation in multisite experiments. Multivar Behav Res 40(1):1-23

Prokop P, Fančovičová J (2013) Does colour matter?: The influence of animal warning coloration on human emotions and willingness to protect them. Anim Conserv 16(4):458-466

Prokop P, Fančovičová J (2016) The effect of hands-on activities on children's knowledge and disgust for animals. J Biol Educ 51(3):305-314

Prokop P, Jančovičová M (2013) Disgust sensitivity and gender differences: An initial test of the parental investment hypothesis. Probl Psychol 21st Century $7: 40-48$

Randler C, Hummel E, Wüst-Ackermann P (2013) The influence of perceived disgust on students' motivation and achievement. Int J Sci Educ 35 (17):2839-2856

Randler C, Ilg A, Kern J (2005) Cognitive and emotional evaluation of an amphibian conservation program for elementary school students. J Environ Educ 37(1):43-52

Randler C, Kummer B, Wilhelm C (2012a) Adolescent learning in the zoo: Embedding a non-formal learning environment to teach formal aspects of vertebrate biology. J Sci Educ Technol 21(3):384-391

Randler C, Wüst-Ackermann P, Vollmer C, Hummel E (2012b) The relationship between disgust, state-anxiety and motivation during a dissection task. Learn Individ Differ 22(3):419-424

Rennie L (2014) Learning science outside of school. In: Lederman NG, Abell SK (eds) Handbook of research on science education, vol II. Routledge, London, pp. 120-144

Rennie L, McClafferty T (1995) Using visits to interactive science and technology centers, museums, aquaria, and zoos to promote learning in science. J Sci Teach Educ 6(4):175-185

Ryan RM, Deci EL (2000) Self-determination theory and the facilitation of intrinsic motivation, social development, and well-being. Am Psychol 55(1):68-78

Salmi H (2012) Evidence of bridging the gap between formal education and informal learning through teacher education. Reflecting Educ 8:45-61

Seybold B, Braunbeck T, Randler C (2014) Primate conservation-an evaluation of two different educational programs in Germany. Int J Sci Math Educ 12 (2):285-305

Snijders TAB, Bosker RJ (1994) Modeled variance in two-level models. Sociol Methods Res 22:342-363

Vedel A (2014) The Big Five and tertiary academic performance: A systematic review and meta-analysis. Pers Individ Dif 71:66-76

Wagler R, Wagler A (2017) Understanding how preservice teachers' fear, perceived danger and disgust affects the incorporation of arachnid information into the elementary science classroom Int J Environ Sci Educ. 12(2):213-231

Ware J, Jain K, Burgess I, Davey GC (1994) Disease-avoidance model: Factor analysis of common animal fears. Behav Res Ther 32(1):57-63

Wilde M, Bätz K, Kovaleva A, Urhahne D (2009) Überprüfung einer Kurzskala intrinsischer Motivation [Testing a short scale of intrinsic motivation]. Z für Didakt der Nat 15:31-45

Wilde M, Hußmann JS, Lorenzen S, Meyer A, Randler C (2012) Lessons with Living Harvest Mice: An empirical study of their effects on intrinsic motivation and knowledge acquisition. Int I Sci Educ 34(18):2797-2810

Wilde M, Urhahne D (2008) Museum learning: A study of motivation and learning achievement. J Biol Educ 42(2):78-83

Winterbottom M (2017) Teaching and learning biology. In: Taber KS, Akpan B (eds) Science education: An international course companion.. SensePublishers, Rotterdam, pp. 343-353

Woods-McConney A, Oliver MC, McConney A, Schibeci R, Maor D (2013) Science engagement and literacy: A retrospective analysis for students in Canada and Australia. Int J Sci Educ 36(10):1588-1608

Wüst-Ackermann P, Vollmer C, Randler C, Itzek-Greulich H (2018) The vivarium: Maximizing learning with living invertebrates-an out-of-school intervention is more effective than an equivalent lesson at school Insects 9(1):1-26

\section{Data availability}

The datasets analyzed during the current study are available in the Dataverse repository: https://doi.org/10.7910/DVN/ARZBCW.

\section{Acknowledgements}

We are grateful to the zoo keeper Peter Lang for his support during the study and for the instruction of the students. Also, our thanks go to our student experts that engaged in these activities. We acknowledge support by Deutsche Forschungsgemeinschaft and Open Access Publishing Fund of University of Tübingen. 


\section{Author contributions}

PWA and CR conceived and designed the study. PWA performed the research. CV analyzed the data. All authors contributed to writing the manuscript.

\section{Additional information}

Supplementary information: accompanies the paper on the Palgrave Communications website (https://doi.org/10.1057/s41599-018-0122-8).

Competing interests: The authors declare no competing interests.

Reprints and permission information is available online at http://www.nature.com/ reprints

Publisher's note: Springer Nature remains neutral with regard to jurisdictional claims in published maps and institutional affiliations. (c) Open Access This article is licensed under a Creative Commons Attribution 4.0 International License, which permits use, sharing, adaptation, distribution and reproduction in any medium or format, as long as you give appropriate credit to the original author(s) and the source, provide a link to the Creative Commons license, and indicate if changes were made. The images or other third party material in this article are included in the article's Creative Commons license, unless indicated otherwise in a credit line to the material. If material is not included in the article's Creative Commons license and your intended use is not permitted by statutory regulation or exceeds the permitted use, you will need to obtain permission directly from the copyright holder. To view a copy of this license, visit http://creativecommons.org/ licenses/by/4.0/.

(C) The Author(s) 2018 